\title{
Electric Car Sharing as an Interdisciplinary Test Ground of Various Fields of Study
}

\author{
Grzegorz Tchorek*, Agnieszka Allen"*, Katarzyna Dziewanowska**, \\ Tomasz Geodecki ${ }^{* * * * *}$, Waldemar Koziot ${ }^{* * * * *}$, Michat Kurtyka*******, \\ Jurand Skrzypek ${ }^{* * * * * * *}$, Filip Targowski $i^{* * * * * * * *}$, Stefan Wójtowicz ${ }^{* * * * * * * * * *}$
}

The aim of the article is to present car sharing, with particular emphasis on electric car sharing, as an interdisciplinary research area. This applies not only to social sciences - management (strategy or marketing), sociology, economics (including the sharing economy), consumer psychology, but also to urban planning, engineering sciences (electrical engineering or energy) and, finally, ecology. Only the use of a broader perspective allows the understanding of the importance of car sharing, including electric vehicles, in contemporary social and economic processes. The diagnosis of factors that may affect the widespread use of car sharing, which we treat as an element of cities' response to congestion and smog, requires a reference to the knowledge of the previously mentioned scientific disciplines.

The core value of this article is that it provides a multi-faceted perspective on the consumer and prosumer, urban mobility and the energy ecosystem from the point of view of the sharing economy and zero/low carbon cars. In recent years, the number of research articles on car sharing has been growing (Ferrero, Perboli, Rosano, \& Vesco, 2018); however, studies written from the point of view of a single, less often two scientific disciplines dominate. We propose to extend this perspective. Although, in research terms, this work is preliminary and exploratory, adopting a broad observation perspective should allow for establishing a dialogue between dis-

* Grzegorz Tchorek - PhD, Centre for Research in Energy Transformation, Mobility and Climate Change, Faculty of Management, University of Warsaw, Poland, https://orcid.org/0000-0003-03077639 .

** Agnieszka Allen - PhD, Centre for Research in Energy Transformation, Mobility and Climate Change, Faculty of Management, University of Warsaw, Poland, https://orcid.org/0000-0002-8228-8049.

*** Katarzyna Dziewanowska - PhD, Centre for Research in Energy Transformation, Mobility and Climate Change, Faculty of Management, University of Warsaw, Poland, https://orcid.org/00000003-1897-0534.

**** Tomasz Geodecki - PhD, Faculty of Public Economy and Administration, Cracow University of Economics, Poland, https://orcid.org/0000-0002-7028-0162.

***** Waldemar Koziol - PhD, Faculty of Management, University of Warsaw, Poland, https://orcid. org/0000-0001-7812-9355.

Michal Kurtyka - PhD, Centre for Research in Energy Transformation, Mobility and Climate Change, Faculty of Management, University of Warsaw, Poland, https://orcid.org/0000-0002-9121-3655. Jurand Skrzypek - MA, Faculty of Management and Social Communication, Jagiellonian University, Institute of Economics, Finance and Management, Poland, https://orcid.org/00000001-7954-6249.

Filip Targowski - MA, Centre for Research in Energy Transformation, Mobility and Climate Change Faculty of Management, University of Warsaw, Poland, https://orcid.org/0000-0001-5743-8810. Stefan Wójtowicz - PhD, Centre for Research in Energy Transformation, Mobility and Climate Change Faculty of Management, University of Warsaw, Poland, https://orcid.org/0000-0002-82716509.

Correspondence address: Faculty of Management, University of Warsaw; 1/3 Szturmowa St., 02-678 Warsaw, Poland; e-mails: tchorek@wz.uw.edu.pl; awysokinska@wz.uw.edu.pl; kdziewanowska@wz.uw.edu.pl; tomasz.geodecki@uek.krakow.pl; WKoziol@mail.wz.uw.edu.pl; jurand. skrzypek@uj.edu.pl. 
ciplines to ensure better formulation of research problems and solve socio-economic dilemmas not only in the field of the sharing economy, and to better introduce the issue of car sharing to the area of management sciences.

Keywords: car sharing, electric vehicle.

Submitted: 16.02.2020 | Accepted: 17.06.2020

\section{Współdzielenie pojazdów elektrycznych jako interdyscyplinarne pole badawcze różnych obszarów nauki}

Celem artykułu jest przedstawienie wspótdzielenia samochodów (car sharing - CS), ze szczególnym uwzględnieniem samochodów elektrycznych jako interdyscyplinarnego obszaru badawczego. Dotyczy to nie tylko nauk spotecznych - zarzadzania (strategii czy marketingu), socjologii, ekonomii (w tym ekonomii wspótdzielenia), psychologii konsumenta, lecz także urbanistyki, nauk inżynierskich (elektrotechniki czy energetyki) czy wreszcie ekologii. Dopiero wykorzystanie szerszej perspektywy pozwala na zrozumienie znaczenia wspótdzielenia pojazdów, a w tym pojazdów elektrycznych, we wspótczesnych procesach spotecznych $i$ ekonomicznych. Diagnoza czynników mogących wptynać na powszechne wykorzystanie car sharingu, który traktujemy jako element reakcji miast na kongestię $i$ smog, wymaga nawiazania do wiedzy z zakresu wskazanych wcześniej dyscyplin naukowych.

Podstawowa wartość niniejszego artykułu polega na tym, że zapewnia wielowatkowe spojrzenie na konsumenta i prosumenta, mobilność miejska $i$ ekosystem energetyczny z punktu widzenia ekonomii wspótdzielenia $i$ samochodu zero/niskoemisyjnego. W ostatnich latach liczba artykułów badawczych dotyczacych car sharingu rośnie (Ferrero, Perboli, Rosano $i$ Vesco, 2018), jednak dominuja opracowania pisane z punktu widzenia pojedynczej, rzadziej dwóch dyscyplin naukowych. Proponujemy rozszerzenie tej perspektywy. Choć w kategoriach badawczych niniejsza praca ma charakter wstępny i eksploracyjny, przyjęcie szerokiej perspektywy obserwacji powinno pozwolić na nawiązanie dialogu między dyscyplinami, aby zapewnić lepsze formutowanie problemów badawczych i rozwiąywanie dylematów spotecznoekonomicznych $w$ dziedzinie ekonomii wspótdzielenia, a też lepiej wprowadzić zagadnienie wspótdzielenia do obszaru nauk o zarzadzaniu.

Słowa kluczowe: car sharing, pojazd elektryczny.

Nadesłany: 16.02.2020 | Zaakceptowany do druku: 17.06.2020

JEL: R40, Q43

\section{Introduction}

Contemporary challenges of urban mobility are related, among other things, to the need to solve the problems of congestion and smog. Responsibility for these negative externalities largely rests with the current model of urban transport with a large share of private mobility. In addition, these cars are used little, and at the same time take up urban space even when they are not moving.

We believe that shared mobility and car sharing are potentially an important part of cities' response to congestion and smog.
Therefore, we pay attention to the need to identify barriers to the widespread use of shared mobility (discouraging consumers from owning a car) and the potential of technology and institutions to mobilise communities to share.

The shared vehicle can replace up to 10 private cars. In addition, the regular use of car sharing services prompts some customers to decide to sell the car and others to postpone their purchase decision. Namazu and Dowlatabadi (2018) indicate possible reductions in the number of private vehicles from 10 to $30 \%$. It is also beneficial that car rental customers are 
more likely to use other forms of shared mobility and are generally greener. This will apply in particular to the sharing of electric cars.

In the light of the above arguments, promoting traditional car sharing is justified. From an air cleanliness point of view, the social benefit appears to be potentially much greater in the case of electric car sharing. However, it should be remembered that for many reasons, joint use of an electric car is a desirable ideal state, which - due to numerous barriers and limitations, which we partially discuss in the article - will not always and not everywhere be the optimal solution. We recognise this problem as an interdisciplinary one and try to present its determinants on the basis of many scientific disciplines, with particular emphasis on management and economics. A special case of car sharing is the sharing of electric vehicles. This is an important technological change and as such, in our opinion, it will be of key importance for the fulfilment of ecological and social expectations related to car sharing.

The first part of the article deals with the issues of the sharing economy and shared mobility. In the second part, we refer to the achievements of social, economic and management sciences in order to trace the mechanisms of choice of means of transport by users. Then we look at car sharing from the perspective of urban planning, the natural environment and the power system. The final section contains a summary and recommendations on the policy for promoting car sharing, including electric car sharing.

\section{The Idea of Car Sharing}

We discuss shared forms of mobility in the context of sharing economy development, which has a potentially stabilizing effect on the economy and the environment, without however being free of barriers and challenges (Hamari et al., 2016; Heinrichs, 2013). Termed collaborative consumption, the process of transactional sharing of goods and services by entities results from changes in the widespread uptake and development of ICT techniques, growing consumer awareness and modification of consumer preferences ("be" instead of "have"), commercial use of social media and economic benefits (Wang \& Zhang,
2012; Hamari et al., 2016). A review of related literature indicates that the multithreaded and interdisciplinary approach to shared mobility is justified by the complex nature of the concepts used to describe the sharing economy. Collaborative consumption, value co-creation, coproduction and prosumerism form a set of categories that are largely related to each other and included in the concept of sharing economy, also referred to as collaborative economy and access economy (Botsman \& Rogers, 2010; Wardak \& Zalega, 2013; Prahalad \& Ramaswamy, 2004; Humphreys \& Grayson, 2008; Ritzer \& Jurgenson, 2010; Belk, 2014). According to analysts' expectations, the sharing economy will embrace various areas of human activity related to space, goods, community and data sharing. This also applies to two important dimensions of sharing in mobility and energy prosumerism - see Figure 1 (Cooper \& Timmer, 2015).

\section{Figure 1. Dimensions of sharing economy}

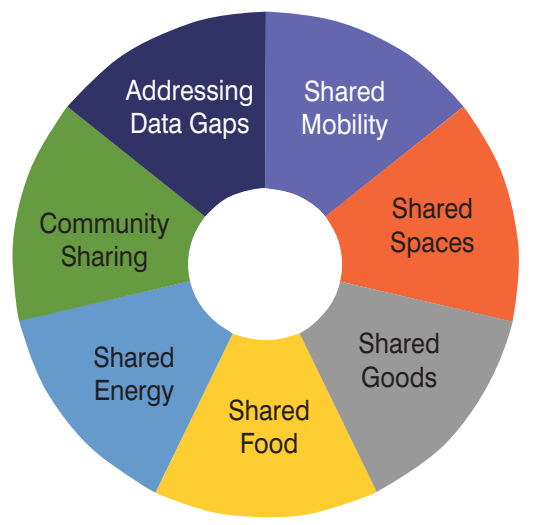

Source: www.localgovsharingecon.com.

Unfortunately, despite many years of experience in the functioning of car sharing systems, which became popular mainly in the first decade of the 21st century, even in the case of well-planned activities and local incentives, car sharing is still not a common and important component of the mobility model in the city. Cities promoting car sharing are still struggling with the problem of an excessive number of private cars, which occupy a large part of the city space.

In London, defined as the benchmark for the implementation of car sharing mobile solutions, less than 200,000 people registered as users of 11 sharing sys- 
tems (data for 2016). Interestingly, even in San Francisco (the cradle of companies such as Uber, Lyft), only 1-2\% of all trips are shared (data for 2014, BCG, 2016). Although the cited data refer to historical readings, and recent years have brought rapid development of car sharing, it remains a generally complementary means of urban transport.

However, it is worth paying attention to the dynamically growing popularity of the service on the largest European market, i.e. Germany (Bundesverband CarSharing e.V.). While at the beginning of 2016 there were 1.26 million users registered (by 220 thousand more than the year before), at the beginning of 2017 this number increased by over 450 thousand, to 1.715 million. The fleet implemented in the stationary car sharing system consisted of 9,400 vehicles, and the so-called free-floating system $-7,800$. The service was available in almost 600 cities, and there were over 150 operators on the market. The popularity of this service in Germany owes its success to proecological social attitudes, long-standing traditions of car sharing, close cooperation between operators and local administration, and the active role of the industry association of car sharing organisations, Bundesverband Car sharing e.V.

Like other forms of shared mobility, car sharing can change the motives for using different modes of transport. Research suggests that users of car sharing, city bikes and urban public transport less often drive their own cars (use them only when needed) and drive fewer kilometres than with their own car (paying each time on the basis of mobility, they become more economical). Shared mobility can therefore be an important factor (impulse) that changes the motivation to make purchasing decisions. Of course, the popularity of car sharing is due to the availability of other forms of public transport - buses, metro (Hu, Chen, Lin, Xie, \& Chen, 2018). However, recent research in the Netherlands shows that the increased propensity to use public transport may depend on the type of car sharing (B2C or P2P) used by the consumer (Münzel, Piscicelli, Boon, \& Frenken, 2019).

A look from the perspective of the psychological aspects of the choice of means of transport suggests that people act habitually and "do not make decisions, but instinctively reach for the keys, without even thinking about the use of alternative means of transport" (Hebel, WyszomirskaGóra, \& Gromadzki, 2017). Providing more information usually improves the assessment of the quality of collective transport and promotes its use. Therefore, the role of local communities in increasing the level of information on the existence, quality and availability of services is important.

It is worth noting that from the point of view of urban space availability and energy consumption (also in electric cars), the most optimal is the promotion of such forms of transport that increase the number of people transported by one car to over 1 (more than one person in a car). In order to stimulate various forms of carpooling and ridesharing, carpool clubs can be useful in setting up a community, breaking down barriers and improving the flexibility and efficiency of planning the service, which requires some coordination of actions on the part of consumers, often at the same time (Correia \& Viegas, 2011). Such forms of shared mobility can play a vital role in ensuring transport to the so-called first and last mile of the travel itinerary that relies primarily on mass transport, which - being the most common and effective form of shared mobility - should also be treated as specific.

\section{Car Sharing as the Subject of Research of Selected Fields of Study}

\subsection{Car Sharing in Economic Theory}

\section{Externalities, Social Optimum and Consumer Optimum}

In principle, car sharing is a service that can, and in practice does, make use of vehicles with different types of drives: combustion, hybrid, gas and electric drive. In the setting of low availability of electric car charging stations or CNG/ LNG filling stations, it is the traditional drive that is the most flexible in terms of availability for customers and their expectations (electric cars still account for a small percentage of the total fleet of car sharing companies).

Although car sharing uses combustion engines (the ones that are increasingly less polluting and the hybrid ones, which, among other things, may enjoy the privi- 
lege of entry into low-emission zones), its contribution to reducing congestion and pollution may also be positive. If research findings are to be believed, a shared car can replace 10 or more private cars. The review of studies on the American market suggests that some car sharing users give up (sell) their cars (from 5 to $55 \%$ of users), and some of them (from 7 to $70 \%$ ) decide not to buy one (Shaheen, Mallery, \& Kingsley, 2012; Becker, Ciari, \& Axhausen, 2018). The findings of research on the German market indicate that a car used in urban car sharing can replace up to 20 private cars, and the service itself reduces ownership of personal cars by $62 \%$ (Loose, 2016). Based on the results of research carried out in the Netherlands, it has been confirmed that car sharing reduces the scale of car trips by approximately $15-20 \%$, and car ownership drops from 1.12 to 0.76 per household (Nijland \& van Meerkerk, 2017).

The above arguments suggest that car sharing based on combustion engines can produce advantageous effects for the city and the environment. Nevertheless, the social benefit would undoubtedly be greater if car sharing operators could be made to use a fleet of electric cars. Due to their range and zero emission nature, electric cars constitute a viable alternative for residents of urbanised areas with a high concentration of population. As these are also areas where the externalities of car ownership associated with emissions and occupation of urban space are the most severe, innovative car use models have the potential for aligning the social optimum with the optimum of the individual consumer.

Numerous examples from cities around the world where car sharing systems operate indicate that this is not an automatic process, or at least its pace is not satisfactory. Hence, the key issue is to identify the barriers: does car sharing respond to the needs of private transport to a similar extent as the existing model based on ownership? Who can car sharing be addressed to? What are the costs of using a car in the car sharing model? Knowing the answers to these questions will allow for selecting appropriate transport and regulatory policy instruments at the local level.

The scale of adverse externalities of transport can be reduced by lowering the marginal social benefit of (decreasing the demand for) moving around in one's own car with a combustion engine in favour of alternative shared and low-emission vehicles. The social optimum will in this case be achieved with fewer vehicles and lower emissions. The scale of the social loss will diminish, which justifies the state's commitment to promoting sharing and electromobility.

\section{The Perspective of the Theory of Consumer Choice in Economics}

The microeconomics theory provides numerous models of consumer decision making. Many of these models build on the neoclassical theory of consumer choice based on the concept of utility. In the light of this theory, consumers choose between available alternatives according to their preferences and budget constraints. When analysing decisions regarding the type of car purchased, it is necessary to start by defining the alternatives available to the consumer. In a narrow sense, there are two alternatives available: zero-/low-emission cars and combustion cars, which are close substitutes for each other.

In the light of the neoclassical theory, the consumer's choice will be influenced by three factors: individual preferences, relative car prices (taking into account operation and maintenance costs) and nominal income. Considering higher nominal costs of buying an electric car and, more broadly, a low-emission one, these costs can be expected to constitute a significant barrier to the development of the market for these vehicles even if consumer preferences shift towards low-emission cars.

The shift of preferences may be difficult in the near future because the range of electric cars is smaller and their recharging takes more time that the refuelling of combustion cars, which renders electric cars potentially less attractive. Technological progress systematically provides new solutions, and this inconvenience can be expected to be eased over several years although the scale of possible progress is not fully predictable. 


\section{Are Consumers Rational? Behavioural Theories and the Role of Information}

The neoclassical theory of consumer choice presents the optimal choice in normative, not positive, categories; in other words, how consumers should make a choice, and not how they actually do. Scientific achievements, especially of most recent years, indicate that consumers do not always act on the assumption of rationality. This can be of particular significance in the case of the car market. For example, from the point of view of the neoclassical theory, consumers should take into account an overall cost of using the car, and not only its nominal price paid at the time of purchase. There are grounds to believe that consumers do not always calculate all costs and the nominal price of the purchase has disproportionately high importance. However, the question whether it is a sign of irrationality or lack of information remains open. This last distinction may be vital from the point of view of pursuing an appropriate policy.

Another example is habit persistence, i.e. the concept whereby today's consumer preferences depend on consumption in a preceding period (Pollak, 1970). Considering that past consumption relied on combustion cars and, even more importantly, models based on individual ownership, the development of the low-emission car sharing market can be very slow and suboptimal. The regulatory policy, the opportunity to test technology, promotion and information as well as encouraging the use of such cars can play an important role in breaking the habit. This is confirmed by the experience good approach (that is, the experience good that needs to be tested to know its quality or to know how well it satisfies the consumer need), and facilitating the first consumption can overcome this barrier. It will also be important to look at the role of pro-environmental attitudes of consumers who can consent to some discomfort associated with the use of a product in exchange for a less harmful impact on the environment (preferences - environmental attitudes, snobbery) (Nelson, 1970).

The use of car sharing causes some inconveniences to consumers who want to satisfy their transport needs. This means that, at least at present, private and shared vehicles are not perfect substitutes. The inconvenience related to the time needed to get to a shared car will be largely offset once autonomous cars appear, when a consumer (or a group of consumers) has an option to order a car delivery to an indicated venue.

On the other hand, however, it should also be remembered that ideal substitutability between a private car and a shared one would also be non-optimal as it could lead to the lack of any significant change in the number of vehicles and a slight decrease in energy consumption. An urban policy oriented towards sustainable development should be aimed at promoting shared forms of transport, including mass transport, in order to increase the car use rate through transportation of more than just one person.

\subsection{The Idea of Car Sharing in the Light of Management Studies}

\section{Consumer Behaviour and Value Co-Creation}

While the outlined achievements of microeconomics and consumer behaviour models can be invoked in the pursuit of answers to the questions about the motives behind purchasing decisions, it is worth referring to concepts and theories rooted in management sciences in order to recognise the potential for altering the purchasing decision. The traditional, macroeconomic view of value, equating it with utility maximisation, neglects many other social, psychological and emotional dimensions of value, or does not sufficiently explore them (Corsaro, 2014).

The approach used in marketing research allows for diagnosing the key dimensions of creating and perceiving value by consumers and the stages of its cocreation in the use of cars, including electric cars, in car sharing. This also applies to patterns of consumer behaviour. This is evidenced by numerous studies conducted in e.g. Poland (Tchorek, Brzozowski, Dziewanowska, Allen, Kozioł, Kurtyka, \& Targowski, 2020), China (Hui, Wang, Ding, \& Liu, 2017; Yoon, Cherry, \& Jones, 2017), Canada (Namazu \& Dowlatabadi, 2018), Germany (Burghard \& Dütschke, 2019) or in French corporations (Fleury, Tom, Jamet, \& Colas-Maheux, 2017), as well as in the field of electric car sharing in Swe- 
den (Sopjani, Stier, Ritzén, Hesselgren, \& Georén, 2019).

Based on an in-depth analysis of nearly 150 papers addressing the concept of value co-creation, Ranjan and Read (2014) distinguished two distinctive areas of consumer activity related to this concept: value co-production and value in use, which can inspire an extensive study of diverse dimensions of perceived value of the service for the client. The resultant diagnosis of key dimensions of value creation and perception by consumers and the stages of value co-creation will allow more efficient control of the system of stimuli and incentives for market development.

The co-production concept corresponds also with the development of prosumer attitudes related to sharing models and the generation of electricity from renewable sources. Particular attention should be paid to the role of a household/individual user as an essential component of the model of clean energy production from renewable sources and its possible use in low-emission cars. In this area, the possibility of using energy storage facilities and providing infrastructure for the fragmented energy market with a potentially large group of small entities (prosumers) will also be vital.

Different forms of sharing, including shared means of mobility, provide an important space for the consumer to be involved in the process of product creation and value co-creation. We assume that the combination of car sharing, electric car, prosumer, smart city and smart grid will result in the creation of service value in the process of "co-production" carried out by the company with the participation of consumers and other road users.

\subsection{Car Sharing from the Point of View of Urban Planning and Environmental Protection}

Urbanisation, Congestion and Emissions in the Road Transport Sector

Rising environmental pollution in cities and the associated higher human mortality are significant environmental aspects providing grounds for the development of both shared mobility and low-emission cars. The ongoing technological developments are accompanied by progressing urbanisation and concentration of population in large agglomerations. According to the data of the UK Department for Transport, a typi- cal private passenger car is used for 6 hours a week, while it is parked for the remaining 162 hours (Bates \& Leibling, 2012). The average car is, therefore, used only for $3.5 \%$ of time, and spends $96.5 \%$ of time parked $(80 \%$ at home, $16.5 \%$ outside the owner's place of residence). These problems are becoming increasingly annoying, so European governments are devoting more and more attention to them, taking actions aimed at finding solutions to these problems through car sharing and electromobility.

The main compound emitted into the atmosphere by the transport sector is carbon dioxide $\left(\mathrm{CO}_{2}\right)$. Its impact is crucial, first and foremost, in the case of greenhouse effect, and the transport sector in Poland - beside the energy sector - is largely responsible for the emission of this gas into the atmosphere, generating $14.3 \%$ of the total national $\mathrm{CO}_{2}$ emissions in 2015 (Bates \& Leibling, 2012). This is mainly due to the road transport sector, which accounts for over $97 \%$ of $\mathrm{CO}_{2}$ emissions in the transport sector. According to Eurostat data, the share of road transport in national $\mathrm{CO}_{2}$ emissions has increased noticeably over the last 9 years, which implies that the sector is increasingly responsible for air quality in Poland. It is, therefore, necessary to take appropriate measures to reduce $\mathrm{CO}_{2}$ emissions in this sector.

One of the ways to reduce emissions may be the dynamic growth of the electric car market and the promotion of the car sharing concept among consumers. It can be expected that an increase in the number of electric cars in Poland will curb the demand for traditional transport fuels and, consequently, the structure of fuels consumed in the road transport sector will change in favour of electricity. The reduction of the share of traditional transport fuels in the energy mix of road transport should lead to a decline in $\mathrm{CO}_{2}$ emissions in this sector.

After taking into account indirect effects, the growth in electricity demand will entail an increase in the consumption of primary energy carriers in the electricity sector, which presently operates chiefly on the basis of high-emission hard coal and lignite. However, a direct reduction of $\mathrm{CO}_{2}$ emissions in road transport can be expected to produce a stronger positive effect in containing domestic $\mathrm{CO}_{2}$ emis- 
sions than an indirect increase in $\mathrm{CO}_{2}$ emissions by increasing the demand for electricity in the energy system. The relationship between the development of the electric car market, a decrease in the consumption of traditional transport fuels and a reduction of greenhouse gas emissions is noticed by such authors as Soltani-Sobh et al. (2017), Ulrich and Lehr (2016), Thiel et al. (2016) or Holland et al. (2016). The topic was also taken up by researchers who, just like the authors of this paper, apply input-output techniques in this regard, e.g. Meade (1995).

Car sharing can catch on mainly locally, in large urban centres, where air quality, including PM2.5 and PM10 concentrations, is of key importance from the point of view of human health. Limiting the use of owned means of transport and the development of shared mobility will help take the strain off road traffic and improve the quality of urban air (more on car sharing and its impact on reducing emissions, see Nijland and van Meerkerk (2017), Rabbitt and Ghosh (2016), Baptista et al. (2014)).

In the future, car sharing can also contribute to bringing down the consumption of transport fuels and, thus, to limiting emissions of pollutants by the economy. However, it must be widely popular and extensively used by the public so that its effect on the reduction of pollutant emissions is noticeable.

\section{How to Incorporate the Electric Car Into Intelligent Urban Mobility?}

Intelligent urban mobility manifests itself in a multitude of ways, but its main goal is to increase the efficiency of the transport system through the deployment of advanced technologies. It seems that the launch of electric cars and other ecofriendly means of transport, combined with appropriate tools integrating various communication and information technologies, can significantly affect the efficiency of the transport system in agglomerations and minimise the associated inconveniences (air pollution, noise, fewer accidents, etc.).

Undoubtedly, an important channel of communication between the city and electric cars will be the infrastructure for charging electric cars, which represents a window for the implementation of the smart city concept. The charging infrastructure is one of the critical factors for the functioning of the electromobility market and, at the same time, an element of value creation for and by the customer. The electric car makes use of the ICT infrastructure and the electrical charging infrastructure. The ICT infrastructure provides billing services for G2V (Grid to Vehicle) and V2G (Vehicle to Grid) services, current information on available charging stations, bi-directional communication between the car and the monitoring station. A necessary component of the infrastructure is a smart grid, which enables communication between all entities of the energy sector. This promotes increased energy efficiency and integrates diffuse sources of energy. The infrastructure embraces, among others, smart meters, which not only provide extensive information but also enable remote control by sending commands to the device. The application of artificial intelligence should allow for more efficient management of the energy network, better energy consumption forecasting, fault prediction, etc.

\subsection{Electric Car Sharing and the Electricity System in the Context of Modern Technologies}

Stabilisation of the Operation of the Electricity System

The demand for electricity fluctuates depending on the time of day. The peak load of the electricity system is in the afternoon and evening hours. During the night hours, we observe a significant decrease in the demand for electricity (night off-peak period), so power need not be generated at full capacity during this period. However, spare capacities must be turned on during the midday and evening peaks, so the electricity system incurs additional costs related to the maintenance of spare capacities at night (production cannot fall below about $40-50 \%$ of the capacity). These costs are usually passed on to energy consumers and are reflected in energy prices.

Charging electric cars at night would allow shifting the load of the national energy system in a way that would reduce the demand for electricity at peak hours and increase it in off-peak periods (Ministry of Energy in Poland, 2016). Electric cars connected to the charging infrastructure can, therefore, be an element of power grid stabilisation (assuming that one mil- 
lion electric cars will need to be charged in Poland, daily electricity production would increase by $11.76 \mathrm{GWh}$, but this increase would occur in the "night off-peak period", which would equalise daily capacities of the electricity system (Kurtyka, 2017)). However, grid operators must provide energy consumers with differentiated prices (with cheaper night rates) to limit car battery charging immediately after their use (usually in the evening when most people leave work) (Salisbury \& Toor, 2016).

The relationship between the charging of electric car batteries and the functioning of the power grid has been investigated by a number of authors, mainly foreign - i.e. Liu et al. (2015), Mu et al. (2014) or Dharmakeerthiet et al. (2011). The literature offers also papers regarding the strictly night battery charging cycle, such as Dubey et al. (2015) or Gajduk et al. (2014). In Poland, few researchers address this issue, probably due to the poor development of the low-emission car market, although some attempts to describe the phenomenon - mostly from a technical point of view - are made, e.g. Guziński et al. (2012, 2014).

A significant value for the customer (in this case - the prosumer) may be revealed also thanks to the production of clean energy from renewable energy sources (RES) for own use and the resale of its excess in the period of increased demand for energy during the day. It is also one of the factors stabilising the electricity system. The development of prosumer energy is supposed to serve the purpose of decentralising energy distribution networks, creating energy sources that are locally independent from electricity system failures and balancing energy demand. Prosumers can not only produce electricity, but also heat, thereby contributing to reducing the emission of pollutants into the atmosphere by burning emission fuels, such as, for example, hard coal. The relationship between prosumers and the electricity system is described in such works as Ahmadyar et al. (2017), Zafar et al. (2017) or World Energy Council (2016).

Analysing the development of the electric car market and prosumer energy, it is essential to take into account certain limitations such as: low level of development of the electric car market, high purchase cost of these cars, limited range of electric cars, negligible number of battery charging points and costs of starting a RES installation.

\section{Electric Car Sharing as a Business Model of the Mobility Ecosystem}

The model based on electric cars is easier to promote thanks to the use of car fleets, which allows for a more efficient management of costs and charging infrastructure. Vehicles operated under car sharing schemes undoubtedly form such a fleet, although a specific one in many aspects. For instance, in the so-called freefloating model, which is the most convenient for the consumer, the effect may be an accidental dispersion of cars that necessitates their relocation. ${ }^{1}$

It seems that operators of electric car fleets are more likely to overcome one of the important barriers to the widespread uptake of electric cars among consumers, i.e. the charging infrastructure. The management of an electric car fleet can offer more favourable financing options (e.g. leasing, long-term rental) of electric car purchase, more efficient management of usage and charging. Even with the still higher price of electric cars, the car sharing service does not have to be significantly more expensive due to the distribution of the cost of buying/renting a car among a larger number of users and due to a more optimal manner of operation than in the case of numerous individual users. The need for passing the higher car purchase cost onto the consumer of the car sharing service can be reduced owing to the opportunity offered by the purchase of cheaper energy at night and its consumption or resale to the power grid during the day. It can be expected that the significant potential for stabilising the power grid will result from the use of electric fleet cars.

Charging cars in the night cycle will improve the absorption capacity of energy generated locally from renewable sources. In order to ensure an outlet for and minimum profitability of energy from RES, local demand is necessary to stabilise energy accumulation and consumption in a 24-hour cycle. The critical mass of the number of electric and low-emission cars that supports the stabilisation of the energy system can be created by promoting fleets, including fleets of shared electric cars. 
Electric car sharing seems to have a potentially significant role to play in this respect because it is generally a local service. The key question is to what extent the car sharing service can be implemented in small towns.

The results of the research conducted by Burghard and Dütschke (2019), which examined the perspectives of electric car sharing in Germany, as a combination of two innovations - car sharing and electric car, should not be ignored either. They indicate the wide acceptance of both innovations (electric car and car sharing), but the segmentation carried out in the study indicated the role of younger people in the absorption of electric car sharing. This applies to young people who, as a couple, do not own a car or are starting a family and use car sharing as a supplement to their own cars (Burghard \& Dütschke, 2019). On the one hand, this will facilitate the transition to zero-emission transport, but on the other hand, it does not necessarily mean such a significant decrease in the number of private cars as described in previous studies.

\section{Conclusion}

Despite the invariably marginal share of shared mobility passenger transport, there are at least a few indications that the car sharing service (in its various mutations) may have better prospects than before (Tchorek, 2017).

First, so far car sharing has been developing in a less favourable technological environment. Technologies, smartphones and mobile applications are, and will be, significantly more available and popular than a few years earlier. At the same time, phones have ceased to have only communication capabilities and have taken over many other functions, including primarily provision of entertainment, but also information and education. The development of the electric car market and the widespread use of information technologies, new business models and prosumer economics can turn car sharing, especially electric car sharing, into a good shared mobility tool. Incorporating the electric car into urban mobility and the energy system thanks to the infrastructure and digitisation will allow for more effective management of the entire transport and energy systems.
Second, technological trends will stimulate social changes conducive to sharing, including car sharing. Consumption patterns evolving along with the attitudes characteristic of the "Y generation" will determine the shape of the personal mobility market. Young people less frequently express willingness/need to possess a car, less often get a driving licence than the previous generation; rather than by a car, their social status is determined by a telephone and electronic devices, which they treat as a source of education, entertainment and "networking". Eco-friendly and pro-health attitudes are on the rise; the role of walking and cycling is increasing (Fournier, Seign, Goehlich, \& Bogenberger, 2015).

Third, the widespread uptake of shared mobility models can support changes in shopping behaviours and travel habits by forcing search for alternative transport solutions (car sharing disaccustoms to using a private car). Research suggests that the users of car sharing, city bicycles and urban transport are less likely to drive their own cars. This means that the widespread uptake of different models of shared mobility may be conducive to the introduction and testing of similar solutions based on the idea of sharing. The development of one of the forms of shared mobility, resulting in resignation from owning a car or reducing its use, may stimulate the development of complementary varieties of sharing. Consumers accustomed to car sharing will usually be more willing (or even forced) to use other forms of shared mobility in the absence of a car (in a car sharing service) than consumers whose mobility relies on their own vehicles.

Fourth, the inclusion of (traditional and electric) car sharing into integrated urban mobility will represent a vital element determining its utility. This requires, among others, collecting, exchanging and managing data for optimal planning of transport process management, but also for managing the electric car fleet. This, in turn, demands parallel progress in smart grid and smart city infrastructure. Improving mobility management and increasing its carbon efficiency call for a more pro-active approach from city and municipality selfgovernments. It is particularly important to integrate mobility around a common application, for example a city card, with car sharing treated as a complementary 
means of transport (such solutions are in place all over the world). This would allow for improving opportunities to use various means of transport, merge and optimise routes (intermodality, interoperability of urban transport).

Fifth, electric car sharing can be a key driver in the promotion of zero-emission mobility. This form of service provides an opportunity to get to know and test the new technology. Due to the advantages of electric cars emphasised by users (quiet, cheap in operation, clean), a potential customer who drives an electric car becomes aware of the benefits derived from the availability of such a service. Car sharing can also help modify and consolidate ecofriendly attitudes. Research suggests that when car sharing customers purchase vehicles for their households, they more often opt for low-emission cars instead of combustion ones (Clewlow, 2016; Schlüter \& Weyer, 2019). Thus, car sharing can be at the forefront of changes in the widespread uptake of low-emission and electric transport. Although car sharing will not significantly alter urban mobility in Poland in the foreseeable future and its potential can be estimated at a maximum of 10-12 thousand vehicles shared throughout the country in a few years' time, it should - for the abovementioned promotional and habit-changing reasons - be a matter of particular concern for central, and especially local, administration.

Sixth, electric car sharing and, more broadly, fleet electric cars can form an important part of the prosumerism ecosystem and the energy system. If, thanks to energy clusters and prosumers, the system is successfully transformed into locally separated, self-balancing energy systems that make an intelligent use of RES, the electric car in the night charging mode can contribute to the stabilisation of the energy system. However, this is conditional upon the existence of price incentives allowing for cheaper charging at night and the provision of night charging infrastructure. More advanced digitisation in the energy sector, which will accelerate the transformation of the model towards distributed energy, is also necessary.

Seventh, for the above reasons, the electric car is not just a change of drive, but it is a modification of the mobility philosophy. In the context of the processes out- lined above, electric car sharing and, more broadly, the electric car and electromobility should be seen not only as a replacement of a combustion car with an electric one but as a factor that can modify the functioning of our ecosystem in which we are increasingly required to take care of the environment. The electric car is essential in itself, but it is much more important as a change in the philosophy of everyday private transport and urban mobility

\section{Endnotes}

1 The consumer collects a vehicle at any point and returns it anywhere, but usually within a designated city zone.

\section{References}

Ahmadyar, A.S., Marzooghi, H., Verbic, G., \& Hill, D.J. (2017). Impact of prosumers on frequency stability of the Australian future grid. Paper presented at 2017 IEEE Power \& Energy Society General Meeting. https://doi.org/10.1109/ PESGM.2017.8274451.

Baptista, P., Melo, S., \& Rolim, C. (2014). Energy, environmental and mobility impacts of car-sharing systems. Empirical results from lisbon, portugal. Procedia - Social and Behavioral Sciences, 111, 28-37. https://doi.org/10.1016/j.sbspro.2014.01.035.

Bates J., \& Leibling D. (2012). Spaced out - Perspectives on parking policy.

BBVA Research. (2016). Urbanization report, European Urbanization Trends. Madrid.

BCG (Boston Consulting Group). (2016). What's ahead for car sharing?. Retrieved on 8 February 2017 from http://www.bcg.de/documents/file206078. pdf.

Becker, H., Ciari, F., \& Axhausen, K.W. (2018). Measuring the car ownership impact of free-floating car-sharing - A case study in Basel, Switzerland. Transportation Research Part D: Transport and Environment, 65, 51-62. https://doi.org/10.1016/j. trd.2018.08.003.

Belk, R. (2014). You are what you can access: Sharing and collaborative consumption online. Journal of Business Research, 67(8), 1595-1600. https://doi. org/10.1016/j.jbusres.2013.10.001.

Botsman, R., \& Rogers, R. (2010). What's mine is yours: The rise of collaborative consumption (1st ed.). Harper Business.

Bundesverband CarSharing e.V. (n.d.). Retrieved on 10 September 2020 from www.car sharing.de. 
Bundesverband CarSharing e.V. (n.d.). Retrieved on 10 September 2020 from www.car sharing.de/ sites/default/files/uploads/pm_car sharing.

Burghard, U., \& Dütschke, E. (2019). Who wants shared mobility? Lessons from early adopters and mainstream drivers on electric carsharing in Germany. Transportation Research Part D: Transport and Environment, 71, 96-109. https://doi.org/10.1016/j. trd.2018.11.011.

Clewlow, R.R. (2016). Carsharing and sustainable travel behavior: Results from the San Francisco bay area. Transport Policy, 51, 158-164. https://doi. org/10.1016/j.tranpol.2016.01.013.

Cooper, R., \& Timmer, V. (2015). Local governments and the sharing economy. One Earth.

Correia, G., \& Viegas, J.M. (2011). Carpooling and carpool clubs: Clarifying concepts and assessing value enhancement possibilities through a Stated Preference web survey in Lisbon, Portugal. Transportation Research Part A: Policy and Practice, 45(2), 81-90. https://doi.org/10.1016/j.tra.2010.11.001.

Corsaro, D. (2014). The emergent role of value representation in managing business relationships. Industrial Marketing Management, 43(6), 985-995. https://doi.org/10.1016/j.indmarman.2014.05.011.

Dharmakeerthi, C.H., Mithulananthan, N., \& Saha, T.K. (2011). Overview of the impacts of plugin electric vehicles on the power grid.

Dubey, A., Santoso, S., Cloud, M. P., \& Waclawiak, M. (2015). Determining time-of-use schedules for electric vehicle loads: A practical perspective. IEEE Power and Energy Technology Systems Journal, 2(1), 12-20. https://doi.org/10.1109/ JPETS.2015.2405069.

Eurostat. (n.d.). Retrieved on 12 September 2020 from http://appsso.eurostat.ec.europa.eu/nui/show. do? dataset $=$ env_ac_ainah_r2\&lang $=$ en.

Feigon, S., \& Murphy, C. (2016). Shared mobility and the transformation of public transit. Transportation Research Board.

Ferrero, F., Perboli, G., Rosano, M., \& Vesco, A. (2018). Car-sharing services: An annotated review. Sustainable Cities and Society, 37, 501-518. https:// doi.org/10.1016/j.scs.2017.09.020.

Fleury, S., Tom, A., Jamet, E., \& Colas-Maheux, E. (2017). What drives corporate carsharing acceptance? A French case study. Transportation Research Part F: Traffic Psychology and Behaviour, 45, 218-227. https://doi.org/10.1016/j.trf.2016.12.004.

Fournier, G., Seign, R., Goehlich, V., \& Bogenberger, K. (2015). Car-sharing with electric vehicles: A contribution to sustainable mobility. Interdisziplinäre Managementforschung, XI. Opatija.

Gajduk, A., Todorovski, M., Kurths, J., \& Kocarev, L. (2014). Improving power grid transient stability by plug-in electric vehicles. New
Journal of Physics, 16(11), 115011. https://doi. org/10.1088/1367-2630/16/11/115011.

Giffinger, R., Fertner, Ch., Kramar, H., Kalasek, R., Pichler Milanović, N., \& Meijers, E. (2007). Smart cities. Ranking of European medium-sized cities. Vienna

Guziński, J., Adamowicz, M., \& Kamiński, J. (2012). Pojazdy elektryczne - rozwój technologii. Układy ładowania i współpraca z siecią elektroenergetyczną. In Automatyka - Elektryka - Zaktócenia (pp. 71-84).

Guziński, J., Adamowicz, M., \& Kamiński, J. (2014). Infrastruktura ładowania pojazdów elektrycznych. Automatyka - Elektryka - Zaktócenia, (1), 74-83.

Hamari, J., Sjöklint, M., \& Ukkonen, A. (2016). The sharing economy: Why people participate in collaborative consumption. Journal of the Association for Information Science and Technology, 67(9), 2047-2059. https://doi.org/10.1002/asi.23552.

Hebel, K., Wyszomirska-Góra, K., \& Gromadzki, M. (2017). Aspekty psychologiczne wybory sposobu podróży miejskich. Prezentacja na warsztatach programu e-bus, Szczecin.

Heinrichs, H. (2013). Sharing economy: A potential new pathway to sustainability. GAIA - Ecological Perspectives for Science and Society, 22(4), 228-231. https://doi.org/10.14512/gaia.22.4.5.

Holland, S.P., Mansur, E.T., Muller, N.Z., \& Yates, A.J. (2016). Are there environmental benefits from driving electric vehicles? The importance of local factors. American Economic Review, 106(12), 3700-3729. https://doi.org/10.1257/ aer.20150897.

Hu, S., Chen, P., Lin, H., Xie, C., \& Chen, X. (2018). Promoting carsharing attractiveness and efficiency: An exploratory analysis. Transportation Research Part D: Transport and Environment, 65, 229-243. https://doi.org/10.1016/j.trd.2018.08.015.

Hui, Y., Wang, W., Ding, M., \& Liu, Y. (2017). Behavior patterns of long-term car-sharing users in China. Transportation Research Procedia, 25, 4662-4678. https://doi.org/10.1016/j. trpro.2017.05.303.

Humphreys, A., \& Grayson, K. (2008). The intersecting roles of consumer and producer: A critical perspective on co-production, co-creation and prosumption: Intersecting roles of consumer and producer. Sociology Compass, 2(3), 963-980. https:// doi.org/10.1111/j.1751-9020.2008.00112.x.

Krajowy Ośrodek Bilansowania i Zarządzania Emisjami (KOBiZE). (2017). Krajowy raport inwentaryzacyjny. Inwentarycacja gazów cieplarnianych $w$ Polsce, Raport na potrzeby Ramowej konwencji Narodów zjednoczonych $w$ sprawie zmian klimatu oraz Protokotu z Kioto. 
Kurtyka, M. (2017). Rozwój elektromobilności w Polsce w kontekście Nowej Ekonomii Strukturalnej. In: A.Z. Nowak (Ed.), Nowa Ekonomia Strukturalna wobec krajów średniego rozwoju. Warszawa: Wydawnictwa Naukowe Wydziału Zarządzania UW.

Liu, Q., Fang, H., Wang, J., \& Yan, S. (2015). The impact of electric vehicle charging on the grid. Paper presented at International Conference on Applied Science and Engineering Innovation (ASEI 2015). Atlantis Press.

Loose, W. (2016). Mehr Platz zum Leben-wie Car sharing Städte entlastet. Ergebnisse des bcs-Projektes Car sharing im innerstädtischen Raum-eine Wirkungsanalyse Endbericht. Berlin.

Meade, D.S. (1995). The impact of the electric car on the US economy: 1998-2005. Economic Systems Research, 7(4), 413-438.

Ministerstwo Energii. (2016). Plan rozwoju elektromobilności w Polsce.

Mu, Y., Wu, J., Jenkins, N., Jia, H., \& Wang, C. (2014). A spatial-temporal model for grid impact analysis of plug-in electric vehicles. Applied Energy, 114 , 456-465. https://doi.org/10.1016/j.apenergy.2013.10.006.

Münzel, K., Piscicelli, L., Boon, W., \& Frenken, K. (2019). Different business models - different users? Uncovering the motives and characteristics of business-to-consumer and peer-to-peer carsharing adopters in The Netherlands. Transportation Research Part D: Transport and Environment, 73, 276-306. https://doi.org/10.1016/j.trd.2019.07.001.

Namazu, M., \& Dowlatabadi, H. (2018). Vehicle ownership reduction: A comparison of one-way and two-way carsharing systems. Transport Policy, 64, 38-50. https://doi.org/10.1016/j.tranpol.2017.11.001.

Nelson, P. (1970). Information and consumer behavior. Journal of Political Economy, 78(2), 311-329. https://doi.org/10.1086/259630.

Nijland, H., \& van Meerkerk, J. (2017). Mobility and environmental impacts of car sharing in the Netherlands. Environmental Innovation and Societal Transitions, 23, 84-91. https://doi.org/10.1016/j. eist.2017.02.001.

Pollak, R.A. (1970). Habit formation and dynamic demand functions. Journal of Political Economy, 78(4), Part 1), 745-763. https://doi. org/10.1086/259667.

Prahalad, C.K., \& Ramaswamy, V. (2004). The future of competition: Co-creating unique value with customers. Harvard Business School Pub.

Rabbitt, N., \& Ghosh, B. (2016). Economic and environmental impacts of organised car sharing services: A case study of Ireland. Research in Transportation Economics, 57, 3-12. https://doi.org/10.1016/j. retrec.2016.10.001.
Ranjan, K.R., \& Read, S. (2016). Value co-creation: Concept and measurement. Journal of the Academy of Marketing Science, 44(3), 290-315. https://doi. org/10.1007/s11747-014-0397-2.

Ritzer, G., \& Jurgenson, N. (2010). Production, consumption, prosumption: The nature of capitalism in the age of the digital 'prosumer'. Journal of Consumer Culture, 10(1), 13-36. https://doi. org/10.1177/1469540509354673.

Salisbury, M., \& Toor, W. (2016). How and why leading utilities are embracing electric vehicles. The Electricity Journal, 29(6), 22-27. https://doi. org/10.1016/j.tej.2016.07.004.

Schlüter, J., \& Weyer, J. (2019). Car sharing as a means to raise acceptance of electric vehicles: An empirical study on regime change in automobility. Transportation Research Part F: Traffic Psychology and Behaviour, 60, 185-201. https://doi. org/10.1016/j.trf.2018.09.005.

Shaheen, S.A., Mallery, M.A., \& Kingsley, K.J. (2012). Personal vehicle sharing services in North America. Research in Transportation Business \& Management, 3, 71-81. https://doi.org/10.1016/j. rtbm.2012.04.005.

Smith, J.B., \& Colgate, M. (2007). Customer value creation: A practical framework. Journal of Marketing Theory and Practice, 15(1), 7-23. https://doi. org/10.2753/MTP1069-6679150101.

Soltani-Sobh, A., Heaslip, K., Stevanovic, A., Bosworth, R., \& Radivojevic, D. (2017). Analysis of the electric vehicles adoption over the united states. Transportation Research Procedia, 22, 203-212. https://doi.org/10.1016/j.trpro.2017.03.027.

Sopjani, L., Stier, J.J., Ritzén, S., Hesselgren, M., \& Georén, P. (2019). Involving users and user roles in the transition to sustainable mobility systems: The case of light electric vehicle sharing in Sweden. Transportation Research Part D: Transport and Environment, 71, 207-221. https://doi.org/10.1016/j. trd.2018.12.011.

Tchorek, G., (2017). Car-sharing conference memo. Gdynia, 14.09.2017, mimeo.

Tchorek, G., Brzozowski, M., Dziewanowska, K., Allen, A., Kozioł, W., Kurtyka, M., \& Targowski, F. (2020). Social capital and value co-creation: The case of a Polish car sharing company. Sustainability, 12(11), 4713. https://doi.org/10.3390/su12114713.

Thiel, C., Nijs, W., Simoes, S., Schmidt, J., van Zyl, A., \& Schmid, E. (2016). The impact of the EU car $\mathrm{CO} 2$ regulation on the energy system and the role of electro-mobility to achieve transport decarbonisation. Energy Policy, 96, 153-166. https:// doi.org/10.1016/j.enpol.2016.05.043.

Ulrich, P., \& Lehr, U. (2016). Economic effects of $e$-mobility scenarios - Intermediate interrelations and consumption. Paper presented at Ecomod, International Conference on Economic Modeling, Lisbon. 
Wang, C., \& Zhang, P. (2012). The evolution of social commerce: The people, management, technology, and information dimensions. Communications of the Association for Information Systems, 31 . https://doi.org/10.17705/1CAIS.03105.

Wardak, P., \& Zalega, T. (2013), Collaborative consumption as a new consumer trend. University of Warsaw, Faculty of Management Research Reports, 7-32.

World Energy Council. (2016). World energy perspective - Variable renewables integration in electricity systems: How to get it right. London.

Yoon, T., Cherry, C.R., \& Jones, L.R. (2017). Oneway and round-trip carsharing: A stated preference experiment in Beijing. Transportation Research Part D: Transport and Environment, 53, 102-114. https:// doi.org/10.1016/j.trd.2017.04.009.

Zafar, R., Mahmood, A., Razzaq, S., Ali, W., Naeem, U., \& Shehzad, K. (2018). Prosumer based energy management and sharing in smart grid. Renewable and Sustainable Energy Reviews, 82, 1675-1684. https://doi.org/10.1016/j. rser.2017.07.018.

Zespół Doradców Gospodarczych TOR. (2017). Elektromobilność w Polsce. Perspektywy rozwoju, szanse i zagrożenia. Warszawa. 